НАУКОВИЙ ВІСНИК

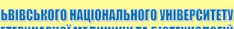

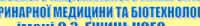
ientific

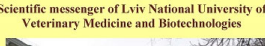

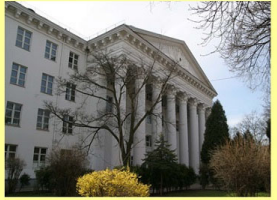

СЕРЯЯ "ЕКОНОМІчН НАУК

Том 22 № 95 2020

Науковий вісник Аьвівського національного університету ветеринарної медицини та біотехнологій імені С.3. Гжицького. Серія: Економічні науки

\author{
Scientific Messenger of Lviv National University \\ of Veterinary Medicine and Biotechnologies. \\ Series: Economical Sciences
}

UDC 338.33:338.432:361.11

\title{
Directions of diversification of agricultural production in Ukraine on the basis of sustainable development
}

\author{
N. L. Khomiuk, N. V. Pavlikha \\ Lesya Ukrainka Volyn national university, Lutsk, Ukraine
}

Article info

Received 07.09.2020

Received in revised form 07.10.2020

Accepted 08.10.2020

Lesya Ukrainka Volyn national university, Voli avenue, 13 , Lutsk, 43025, Ukraine.

Tel.: +38-050-500-89-25

E-mail:nataljabilous@gmail.com
Khomiuk, N. L., \& Pavlikha, N. V. (2020). Directions of diversification of agricultural production in Ukraine on the basis of sustainable development. Scientific Messenger of Lviv National University of Veterinary Medicine and Biotechnologies. Series: Economical Sciences, 22(95), 4551. doi: $10.32718 /$ nvlvet-e9508

The article substantiates the directions of diversification of agricultural production in Ukraine on the basis of sustainable development in order to improve the quality of life of the rural population, ensure the competitiveness of rural areas, achieve environmental safety. In the process of research in the areas of diversification of agricultural production used a monographic and graphic methods and scientific generalization. Diversification is seen as the diversification of the object of study and giving it a multidisciplinary, combined nature, which is realized by expanding the scope of the enterprise. Attention is drawn to the fact that in rural areas diversification should be based on the basis of sustainable development and on the relocation of resources to new areas of agricultural and non-agricultural activities. It is proposed to diversify agricultural production in the areas of expanding the range and markets, support and development of organic production, increase the volume of niche crops, which will contribute to the production of agricultural products with a larger share of value added, increase exports of agricultural products, expand the population. Declining trends in agricultural production have been identified in parallel with the growth of more profitable types of crop and livestock products (rapeseed, sunflower, pigs, poultry). It is emphasized that during the formation of the species structure of agricultural production it is necessary to take into account not only the demand for it but also to ensure efficient and rational use of available labor, raw materials, land, technical, technological, financial and other resources. The expediency of growing niche crops (garlic, sorghum, chickpeas, mustard, nuts, flax) is substantiated, the main advantage of which is the growth of demand for these products in combination with small production volumes, which will expand markets and increase the competitiveness of agricultural production. It is proved that in Ukraine there are all the prerequisites for the spread of organic land use as a direction of diversification of rural development on the basis of sustainable development. This allows not only to make a profit, but also to produce environmentally friendly food and reduce the destructive anthropogenic impact on the environment. Further research should be carried out in the field of formation of the scientific concept, development of the mechanism of organizational and economic support and selection of priorities of diversification of agricultural production.

Key words: assortment, market, organic production, niche crops, rural areas, rural population

\section{Напрями диверсифікації сільськогосподарського виробництва в Україні на засадах сталого розвитку}

\author{
Н. Л. Хомюк, Н. В. Павліха
}

Волинський наџіональний університет імені Лесі Украӥнки, м. Луцьк, Украӥна

У статті обтрунтовано напрями диверсифікаџії сільськогосподарського виробництва в Украӥні на засадах сталого розвитку з метою підвищення якості життя сільського населення, забезпечення конкурентоспроможності сільських територій, досягнення екологічної безпеки. У процесі проведення досліджень напрямів диверсифікаиії сільськогосподарського виробництва на засадах сталого розвитку використано монографічний та графічний методи, й наукового узагальнення. Диверсифікацію розглянуто як 
урізноманітнення об'єкта дослідження й надання йому багатогалузевого, комбінованого характеру, щзо реалізується за допомогою розиирення сфер діяльності підприємства. Звернено увагу на те, щзо на сільських територіях диверсифікація повинна трунтуватися на засадах сталого розвитку та передислокаиї ресурсів у нові напрями сільськогосподарської й несільськогосподарської діяльності. Запропоновано диверсифікацію сільськогосподарського виробниџтва здійснювати в напрямах розиирення асортименту та ринків збуту продукиії, підтримки та розвитку органічного виробництва, збільшення обсягів вирошування нішевих культур, щчо сприятиме виробництву сільськогосподарської продукиії з більшою часткою доданої вартості, зростанню експорту виробленої сільськогосподарської продукиї, розширенню сфер зайнятості й доходів сільського населення. Виявлено спадні тенденції у виробництві сільськогосподарської продукиії паралельно із зростанням обсягів вирощування більш рентабельних видів продукціі рослинництва та тваринництва (ріпаку, соняшнику, свиней, птиці). Акиентовано на тому, цуо під час формування видової структури вирощування сільськогосподарської продукиї потрібно враховувати не лише попит на неї, а й забезпечити ефективне та раціональне використання наявних трудових, сировинних, земельних, технічних, технологічних, фінансових й іниих ресурсів. Обтрунтовано дочільність вирощування нішевих культур (часнику, сорго, нуту, гірчиці, горіхів, льону), основною перевагою якого є зростання попиту на иі види продукиї в поєднанні з невеликими обсягами виробниитва, щчо сприятиме розширенню ринків збуту й підвищенню конкурентоспроможності сільськогосподарського виробництва. Доведено, щзо в Украӥні наявні всі передумови для поширення органічного землекористування як напряму диверсифікації розвитку сільських територій на засадах сталого розвитку. Це дає змогу не лише отримувати прибутки, а й виробляти екологічно безпечні продукти харчування та змениити деструктивний антропогенний вплив на навколишнє середовище. Подальші дослідження доцільно здійснювати у сфері формування наукової концепції, розробки механізму організаційно-економічного забезпечення й виокремлення пріоритетів диверсифікації сільськогосподарського виробництва.

Ключові слова: асортимент, ринок збуту, органічне виробнищтво, нішеві культури, сільські територій, сільське населення.

\section{Ветуп}

Диверсифікація вважається елементом стратегічного управління, який виник як результат максимального задоволення попиту споживачів та збереження конкурентних переваг фірм. Потрібно зазначити, що диверсифікацію все активніше обговорюють науковці та практики як інструмент управління розвитком суб'єктів господарювання, регіонів, об'єднаних територіальних громад, що потребує окреслення напрямів реалізації залежно від об'єкта управління та відповідно до теоретико-методологічного роз'яснення.

У зарубіжній економічній науці проблеми диверсифікації розкрито в працях І. Ансоффа, Ф. Котлера, Дж. Еванса, Б. Бермана та ін. Також вагомий внесок у дослідження процесу диверсифікації в агарній сфері зробили вітчизняні фахівці, наприклад Т. Зінчук, О. Зоренко, О. Згурська, І. Кульчій, Ф. Важинський, А. Колодійчук, Н. Маслак, О. Молнар, Т. Панюк, М. Плотнікова, В. Ткачук та ін. Попри значний обсяг публікацій із дослідженої тематики, не існує єдиного підходу до трактування поняття «диверсифікація». Окрім того, віддаючи належне наявним здобуткам, зазначимо, що недостатньо вивченими залишаються деякі питання, пов'язані саме $з$ оцінкою стану та обгрунтуванням напрямів диверсифікації сільськогосподарського виробництва на засадах сталого розвитку.

Метою дослідження є обгрунтування напрямів диверсифікації сільськогосподарського виробництва в Україні на засадах сталого розвитку з метою підвищення якості життя сільського населення; забезпечення конкурентоспроможності сільських територій; досягнення екологічної безпеки на засадах сталого розвитку.

Для досягнення поставленої мети вирішуються наступні завдання: розкрити сутність поняття «диверсифікація сільськогосподарського виробництва», оцінити стан розвитку аграрного сектору економіки в Україні, окреслити напрями диверсифікації сільськогосподарського виробництва.

\section{Матеріал та методи досліджень}

У процесі проведення досліджень використано загальнонаукові методи, серед яких: монографічний при теоретичному обгрунтуванні поняття «диверсифікація сільськогосподарської діяльності»; економікостатистичний, графічний - для виявлення сучасних тенденцій розвитку сільськогосподарського виробництва в регіоні та Україні, наукового узагальнення при окресленні напрямів диверсифікації сільськогосподарського виробництва на сільських територій в Україні.

Інформаційною базою дослідження слугували статичні дані, наукові праці вітчизняних і зарубіжних авторів, електронні ресурси, представлені в мережі Інтернет, результати власних досліджень авторів тощо.

\section{Результати та їх обговорення}

Термін “диверсифікація” виник в Європі в середині 50-х рр. ХХ ст. у зв’язку з необхідністю пристосування бізнесу до швидких структурних змін та посилення конкурентної боротьби. Дефініція “диверсифікація" походить від латинського “diversus" - різний, віддалений і “facere" - робити. Вважаємо, що диверсифікація - це урізноманітнення об'єкта дослідження й надання йому багатогалузевого, комбінованого характеру, що реалізується за допомогою розширення сфер діяльності підприємства.

Запропоновано диверсифікацію сільськогосподарського виробництва здійснювати на засадах сталого розвитку в напрямах розширення асортименту та ринків збуту продукції, підтримки та розвитку органічного виробництва, збільшення обсягів вирощування нішевих культур. Це сприятиме виробництву сільськогосподарської продукції з більшою часткою доданої вартості, зростанню експорту виробленої сільськогосподарської продукції, розширенню сфер зайнятості й доходів сільського населення.

В наукових працях виокремлено диверсифікацію сільськогосподарського виробництва як одного 3 напрямів диверсифікації розвитку сільських територій, 
що сприяє досягненню цілей сталого розвитку (Pavlikha, \& Khomiuk, 2019). Парадигму сталого розвитку сільських територій доцільно покласти в основу розробки концепції диверсифікації розвитку цих територій, побудованої на засадах комплексності, міждисциплінарності та синергетики, цільовим орієнтиром якої $\epsilon$ ефективне використання наявних і потенційних можливостей розвитку сільських територій для підвищення якості життя сільського населення; посилення конкурентних переваг цих територій та досягнення екологічної безпеки в умовах децентралізації (Khomiuk, \& Pavlikha, 2019).

Н. Павліха та М. Войчук обгрунтували, що регіональними передумовами, які мають безпосередній вплив на сталий розвиток територій, є: інституційні, соціальні, економічні, екологічні передумови (Pavlikha, \& Voichuk, 2018). Науковцями здійснено аналіз сталого розвитку сільських територій в умовах децентралізації на основі застосування методики, яка грунтується на визначення часткових індексів розвитку соціальної сфери, економічної та екологічної ситуацій та розрахунку на їх основі інтегрального індекси сталого розвитку сільських територій України (Khomiuk, et al., 2020).

За результатами оцінки стану диверсифікації сільськогосподарського виробництва у Волинській області виявлено зменшення кількості зайнятого населення у сільському, лісовому та рибному господарствах 3 91,9 тис. осіб у 2000 р. до 12,1 тис. осіб у 2018 р. (майже у 8 разів).

Спадні тенденції також прослідковуються у виробництві сільськогосподарської продукції (табл. 1) паралельно із зростанням обсягів вирощування більш рентабельних видів продукції рослинництва та тваринництва (ріпаку, соняшнику, свиней, птиці).

Таблиця 1

Виробництво продукції сільського господарства у Волинській області

\begin{tabular}{|c|c|c|c|c|c|c|c|c|}
\hline $\begin{array}{c}\text { Вид сільськогоспода- } \\
\text { рської продукції }\end{array}$ & 1990 & 1995 & 2000 & 2005 & 2010 & 2015 & 2018 & $\begin{array}{l}\text { Абс. приріст } \\
\text { за 2018-1990 }\end{array}$ \\
\hline 1 & 2 & 3 & 4 & 5 & 6 & 7 & 8 & 9 \\
\hline \multicolumn{9}{|c|}{ Продукція рослинництва } \\
\hline $\begin{array}{l}\text { Культури зернові та } \\
\text { зернобобові, тис. т }\end{array}$ & 896,1 & 704 & 329,6 & 350 & 252,5 & 572 & 793,9 & $-102,2$ \\
\hline Цукровий буряк, тис. т & 1168,1 & 515,1 & 286,9 & 286,7 & 328 & 277,9 & 398,4 & $-769,7$ \\
\hline Ріпак і кольза, тис. т & 8,5 & 1,6 & 3,2 & 5,9 & 37,5 & 85,2 & 136 & 127,5 \\
\hline Соя, тис. т & 0 & 0 & 0 & 0,3 & 17 & 68,5 & 98,2 & 98,2 \\
\hline Соняшник, тис. т & 0 & 0 & 0 & 0,2 & 0,2 & 5,2 & 69,5 & 69,5 \\
\hline Картопля, тис. т & 484,4 & 26,6 & 19,3 & 9,6 & 12 & 9,8 & 5,7 & $-478,7$ \\
\hline Культури овочеві, тис. т & 84,1 & 15,2 & 9,6 & 7,1 & 10,7 & 10,8 & 12,8 & $-71,3$ \\
\hline $\begin{array}{l}\text { Культури плодові та } \\
\text { ягідні, тис. т }\end{array}$ & 3,6 & 2,8 & 1 & 0,3 & 1,8 & 5,5 & 9,3 & 5,7 \\
\hline \multicolumn{9}{|c|}{ Продукція тваринництва } \\
\hline М'ясо, тис. т & 108,2 & 54,1 & 43,4 & 58,5 & 94,5 & 120,5 & 113,7 & 5,5 \\
\hline $\begin{array}{l}\text { в т. ч. яловичина та } \\
\text { телятина, тис. т }\end{array}$ & 68,2 & 30 & 22,5 & 17,7 & 14 & 10,2 & 7 & $-61,2$ \\
\hline в т. ч. свинина, тис. т & 28,8 & 18,4 & 16,6 & 24,5 & 38,2 & 36,3 & 38,4 & 9,6 \\
\hline $\begin{array}{l}\text { в т. ч. м'ясо птиці, } \\
\text { тис. т. }\end{array}$ & 9 & 4,7 & 3,6 & 15,4 & 41,4 & 72,9 & 67,2 & 58,2 \\
\hline Молоко, тис. т & 848,1 & 564,1 & 458,2 & 550,6 & 450,2 & 425,2 & 391,1 & -457 \\
\hline Яйця, млн шт. & 311,4 & 198,9 & 158,5 & 219,6 & 181,6 & 193,9 & 203 & $-108,4$ \\
\hline Вовна, т & 327 & 66 & 29,6 & 22,7 & 19,7 & 17,2 & 19,1 & $-307,9$ \\
\hline
\end{tabular}

Джерело: систематизовано авторами на основі статистичних даних (Derzhavna sluzhba statystyky Ukrainy, 2019)

Загалом по Україні у 1990-2018 рр. спостерігаємо стабільну тенденцію зростання обсягів виробництва зернових культур від 51 млн т у 1990 р. до 70,1 млн т у 2018 р., хоч а у 2000 р. цей показник становив 24,5 млн т. Однак, у 2013-2017 рр. виробництво зерна перестало зростати і стабілізувалося на рівні 6065 млн т. Основними перешкодами для подальшого зростання зерновиробництва, на нашу думку, є погіршення стану грунтів, недотримання режиму сівозмін та зростання частки високорентабельних, але виснажливих для грунту, культур (соняшник, соя). Зміну структури посівних площ основних сільськогосподарських культур у 1990-2018 рр. в Україні представлено на рис. 1. Трансформація структури зерновиробництва в Україні відбулася не лише з економічних причин, а й у зв'язку із зміною клімату.
Як бачимо, понад 50 \% посівних площ займають зернові та зернобобові культури. На рис. 2 відображено структуру їхнього валового збору в Україні у 2018 р. Виявлено, що значну частину обсягів збору становлять кукурудза та пшениця.

Розширення асортименту та ринків збуту продукиії є одним із шляхів реалізації диверсифікації сільськогосподарського виробництва. Великий вплив на розвиток сільськогосподарських підприємств та сільських територій загалом мають асортимент, структура виробництва та реалізації сільськогосподарської продукції.

Товаровиробникам, які планують диверсифікувати власне сільськогосподарське виробництво шляхом розширення наявного асортименту, потрібно передусім оцінити ринковий попит на продукцію (Khomiuk, 
2019). Це дасть змогу виявити, яка сільськогосподарська продукція на сьогодні задовольнить потреби та вимоги потенційних споживачів. Але при формуванні асортименту, структури вирощування та випуску продукції аграрне підприємство повинно враховувати не лише попит на ці види продукції, а й забезпечити найбільш ефективне використання наявних трудових, сировинних, земельних, технічних, технологічних, фінансових та інших ресурсів 3 мінімізацією антропогенного впливу на навколишнє середовище. Окрім того, необхідно дослідити конкурентне середовище сільськогосподарського ринку, щоб отримати переваги перед потенційними конкурентами.

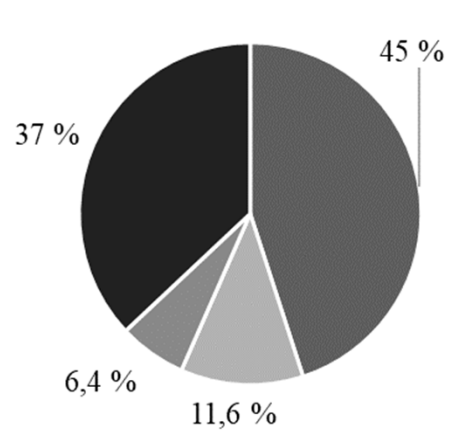

$1990 \mathrm{p}$.

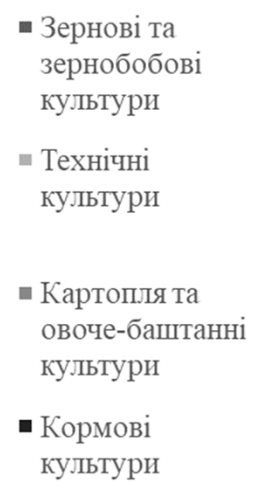

культури

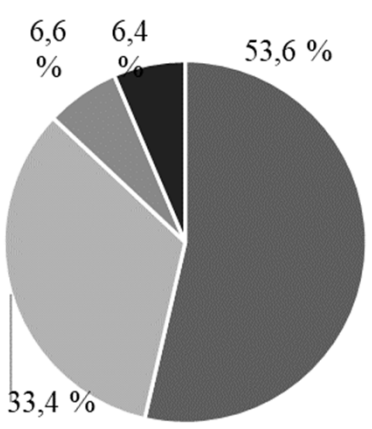

2018 p.

Рис. 1. Структура посівних площ основних сільськогосподарських культур у 1990-2018 рр. в Україні Джерело: побудовано на основі статистичних даних (Derzhavna sluzhba statystyky Ukrainy, 2019)

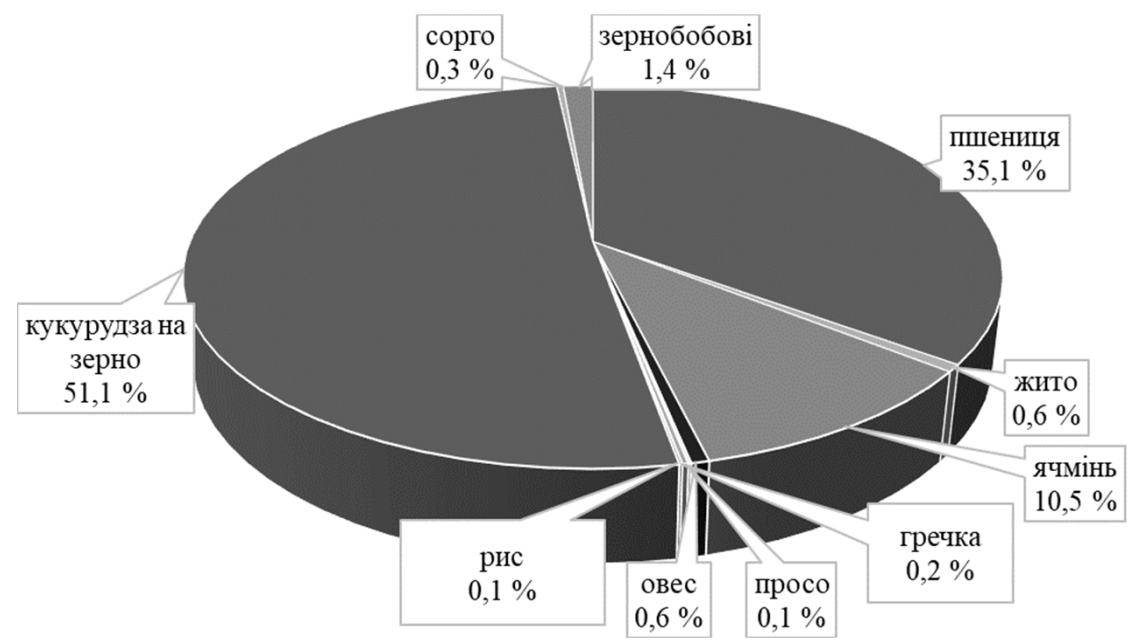

Рис. 2. Структура валового збору зернових та зернобобових культур в Україні у 2018 р.

Джерело: побудовано авторами на основі статистичних даних (Derzhavna sluzhba statystyky Ukrainy, 2019)

Формування товарної політики сільгоспвиробників на маркетингових засадах, на думку У. Росоли, дасть можливість виробникам виокремити потреби ринку, його величину, гнучко зреагувати на зміну попиту на ринку. Через сезонність продукції підприємствам доцільно диверсифікувати свою діяльність і розширити номенклатуру чи асортимент продукції. Саме політика диверсифікації дає змогу компенсувати втрати на одному із ринків, отримавши прибуток на іншому (Rosola, 2018).

П. Матвеєв вважає, що впровадження нових технологій в сільському господарстві призводить до істотного росту продуктивності використання ресурсного потенціалу, відповідно відбувається відносне зниження цін на продукти харчування, від чого виграють люди 3 низьким доходом. Тому поступово цей сектор економіки перетворюються в конкурентоспроможний, порівняно 3 іноземними конкурентами, що спричиняє позитивні зміни для економіки країни загалом (Matvieiev, 2019). Тригуба А. також звертає увагу на розширення асортименту у тваринництві (Tryhuba, et al., 2019).

Розширення асортименту продукції та ринків збуту, на нашу думку, забезпечить збільшення обсягів реалізації вирощеної продукції внаслідок оптимізації структури асортименту; досягнення конкурентних переваг через розширення асортименту, залучення нових споживачів; вихід на нові сегменти ринку; зростання експорту, розширення сфер зайнятості та доходів сільського населення.

Одним із шляхів реалізації диверсифікації сільськогосподарського виробництва на засадах сталого розвитку є підтримка органічного виробництва. Згідно з Законом України "Про основні принципи та вимоги до органічного виробництва, обігу та маркування органічної продукції” органічне виробництво - 
це сертифікована діяльність, пов'язана з виробництвом сільськогосподарської продукції (у тому числі всі стадії технологічного процесу, а саме первинне виробництво (включаючи збирання), підготовка, обробка, змішування та пов'язані з цим процедури, наповнення, пакування, переробка, відновлення та інші зміни стану продукції), що провадиться із дотриманням вимог законодавства у сфері органічного виробництва, обігу та маркування органічної продукції (Pro osnovni pryntsypy ta vymohy do orhanichnoho vyrobnytstva, obihu ta markuvannia orhanichnoi produktsii: Zakon Ukrainy, 2018).

Виявлено збільшення у світі попиту на продукти харчування, в тому числі й на органічні. Розвиток органічного сільського господарства $є$ важливим тому, що він надає можливість виробляти та вирощувати екологічно безпечні продукти харчування та сприяє досягненню перспектив сталого розвитку сільських територій (Khomiuk, 2019).

На думку Є. Милованова, органічна детермінанта стала економічним індикатором соціальноекологічного прогресу в агровиробництві. Адже провідні держави світу сконцентрували свою увагу на створенні таких сільськогосподарських систем, які здатні не лише забезпечити суспільство харчовими продуктами та принести прибуток виробникам, але й надати конкретні соціально-екологічні переваги. Тому багаторічна практика органічного господарювання свідчить про підвищення рівня збалансованості соціальної, економічної та екологічної складових сільсько- господарських виробничих систем у часовому та просторовому вимірах (Mylovanov, 2018), що є головними цілями сталого розвитку.

Варто звернути увагу на те, що органічне сільське господарство швидко розвивається в усьому світі. Нині 4,2 \% сільськогосподарських угідь у Європейському Союзі зайняті виробництвом екологічної продукції. Найбільші ділянки відведені під органічне виробництвом - в Австрії, де вони становлять 13,4\% від загальних площ, а найменші - в Ірландії (0,95\%), Румунії (0,77 \%) та Мальті (0,2 \%).

За площею сільськогосподарських угідь та ріллі Україна посідає перше місце в Європі. Аграрний сектор займає одне з провідних місць у національній економіці України. Площа сільськогосподарських угідь України станом на 1 січня 2017 р. становила 42,7 млн га, або 70 \% від загального земельного фонду, із них на ріллю припадало 325 млн. га, або 78,4 \%. Згідно з даними Офісу підтримки реформ при Міністерстві аграрної політики та продовольства України станом на 1 січня 2017 р. площа сільськогосподарських земель 3 органічним статусом становила 289551 га; площа сільськогосподарських земель перехідного періоду - 91622 га; загальна площа сільськогосподарських земель 3 органічним статусом та перехідного періоду - 381173 га; частка органічних земель від загальної площі сільськогосподарських земель - 0,89 \% (Trofimtseva, \& Prokopchuk, 2018). Динаміку площ органічних земель в Україні подано на рис. 3.

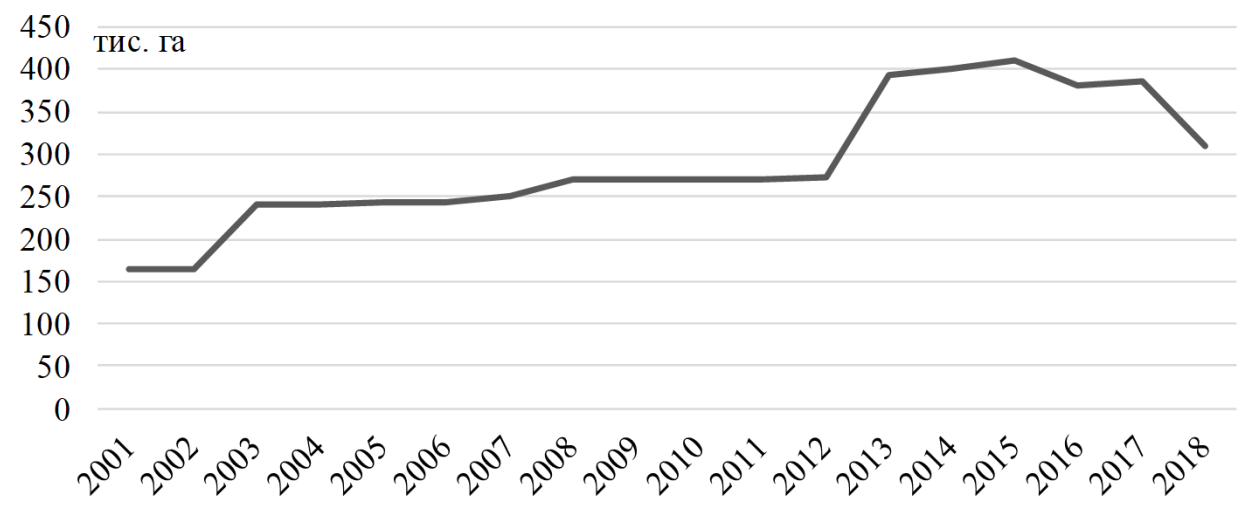

Рис. 3. Динаміка площ органічних земель в Україні

Джерело: побудовано авторами на основі (Trofimtseva, \& Prokopchuk, 2018)

В Україні придатні для розвитку органічного землеробства аж 19 \% сільськогосподарських угідь. Однак, дуже мало господарств в нашій державі ризикують освоювати екологічне виробництво у зв'язку 3 тим, що для більшості населення перехід на органічну продукцію за значно вищими цінами ії придбання не можливий.

Нині в Україні, як зазначають Т. Кунділовська та Е. Зеленянська, $є$ сертифікованими такі органічні товари, як: зернові, бобові, олійні культури, овочі, фрукти, ягоди (свіжі, сушені, морожені), виноград, гарбузи, дині, кавуни, ефіроолійні культури, молоко, м'ясо, яйця, гриби, горіхи, мед. Попит на ці найбільш популярні групи продуктів в іноземних державах визначає формування асортиментної політики для органічних операторів в Україні, адже до 70,0 \% виробленої органічної продукції спрямовується на експорт, і тільки 30,0 \% споживається на внутрішньому ринку (Kundilovska, \& Zelenianska, 2018).

На рис. 4 відображено площу посівних органічних культур в Україні у 2017 р., які увійшли в ТОП-10.

Кількість органічних операторів також 3 кожним роком зростає. Наприклад, станом на 14 листопада 2019 р. їх кількість становила 617. Вважаємо, що органічне виробництво $є$ одним із пріоритетних видів сільськогосподарської діяльності на засадах сталого розвитку в умовах сьогодення. 3 огляду на це, він дає змогу не тільки отримувати прибутки, а й виробляти екологічно безпечні продукти харчування та зменшити негативний антропогенний вплив на довкілля. 


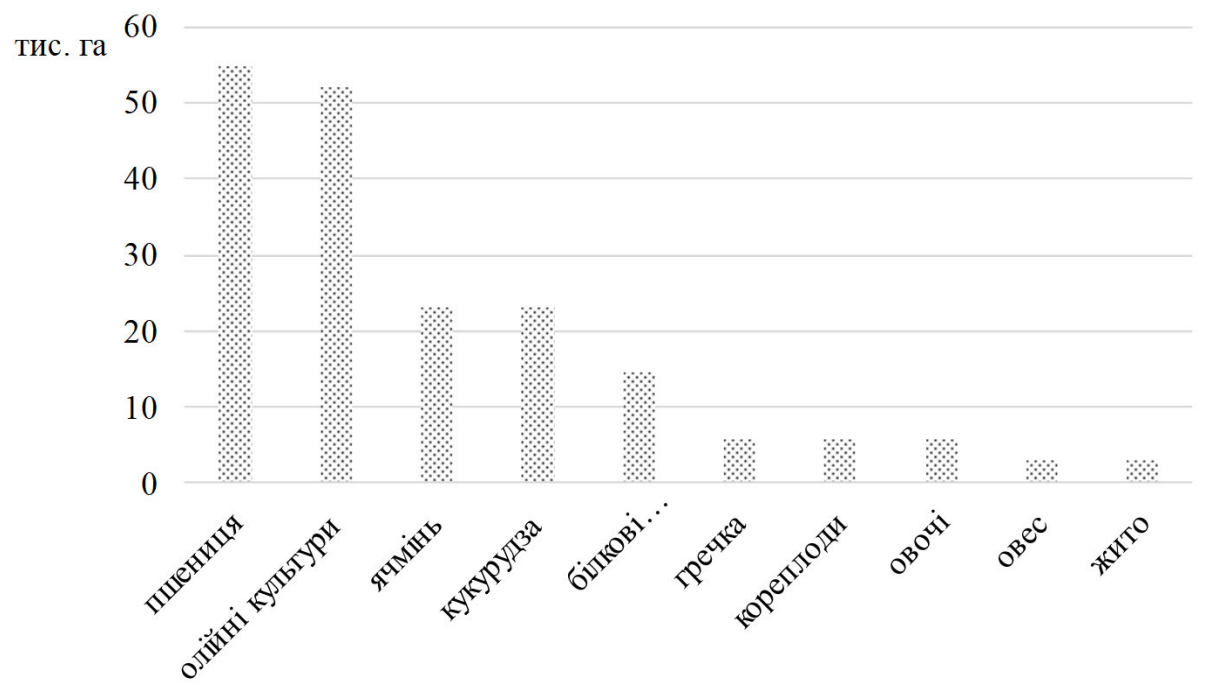

Рис. 4. Посівні площі органічних культур в Україні у 2017 р.

Джерело: побудовано на основі (Ahrobiznes Ukrainy, 2018-2019)

Одним із шляхів реалізації диверсифікації розвитку сільських територій в умовах децентралізації $\mathrm{\epsilon}$ вирощування нішевих культур. В економіці нішу розглядають як незайнятий або недостатньо освоєний вузький сегмент ринку товарів і послуг, за освоєння якого продавець отримує прибуток.

На думку I. Черевко, основними критеріями, що дають підстави для віднесення тих чи інших сільськогосподарських культур до категорії нішевих, є малорозвиненість конкретного ринку, перевищення попиту над пропозицією, низька конкуренція у секторі виробництва продукції, високі закупівельні ціни та високий рівень дохідності з одиниці площі вирощування за відносно мінімальної потреби в цій площі, висока питома частка нематеріальної (інтелектуальної) складової в доданій вартості й ціні реалізації. Науковець акцентує увагу на тому, що важливою особливістю нішевих культур $є$ й те, що вони досить ресурсомісткі, а їхнє виробництво досить складно або взагалі неможливо масштабувати (Cherevko, 2018).
Про доцільність вирощування нішевих культур в Україні свідчить те, що дрібним підприємствам важко вирощувати овочі та фрукти великими партіями й конкурувати за обсягами, партіями та якістю 3 великими сільськогосподарськими підприємствами. Тому вони змушені диверсифікувати асортимент продукції та освоювати непопулярні ніші, що дозволяє агровиробникам отримувати більший прибуток.

Як бачимо з рис. 5, обсяги вирощування нішевих культур в Україні зростають 3 кожним роком. Перспективними сільськогосподарськими нішевими напрямами виробництва $€$ вирощування часнику, артишоку, ягідне виробництво (ожини, лохини), вирощування нових видів тварин, риби. Звернемо увагу, що вирощування рослин, не призначених для певного регіону або використання під посів неякісного чи непристосованого під певний район насіння можуть позначатися на продуктивності вирощеної культури, в результаті чого сільськогосподарський товаровиробник може зазнати збитків.

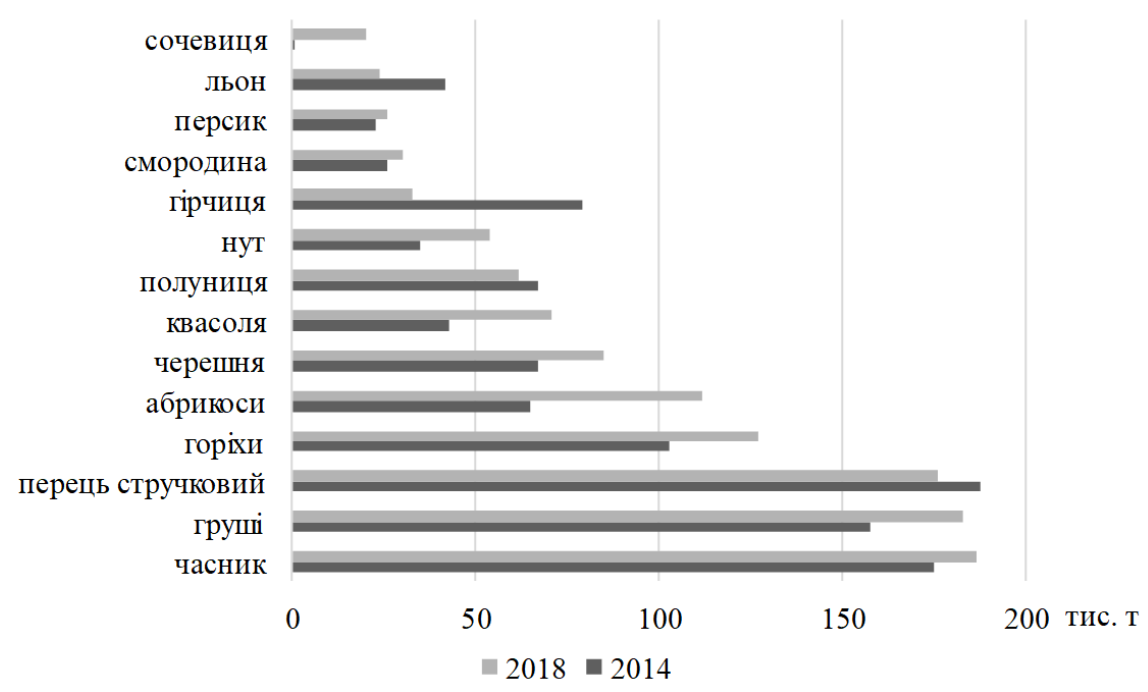

Рис. 5. Динаміка обсягів вирощування нішевих культур в Україні Джерело: побудовано на основі (Ahrobiznes Ukrainy, 2018-2019) 
Забезпечення диверсифікації сільськогосподарського виробництва на засадах сталого розвитку повинно грунтуватися на засадах єдності й цілісності 3 обов'язковим врахуванням географічних, економічних, екологічних, етнічних та демографічних особливостей сільських територій, на яких здійснюється діяльність агровиробників (Khomiuk, 2020).

\section{Висновки}

Під диверсифікацією запропоновано розуміти урізноманітнення об'єкта дослідження й надання йому багатогалузевого, комбінованого характеру, що реалізується за допомогою розширення сфер діяльності підприємства. На сільських територіях диверсифікація грунтується на передислокації ресурсів у нові напрями сільськогосподарської й несільськогосподарської діяльності. Вважаємо, що розширення асортименту та ринків збуту сільськогосподарської продукції, органічне виробництво, вирощування нішевих культур сприятимуть диверсифікації сільськогосподарського виробництва на засадах сталого розвитку та забезпечать зростання експорту продукції, розширення сфер зайнятості i, відповідно, доходів сільського населення.

Перспективи подальших досліджень. Подальші дослідження проводитимуться щодо формування наукової концепції, розробки механізму організаційно-економічного забезпечення й виокремлення пріоритетів диверсифікації сільськогосподарського виробництва в умовах децентралізації.

\section{References}

Ahrobiznes Ukrainy 2018-2019: infohrafichnyi dovidnyk. URL: https://superagronom.com/news/8304opublikovano-infobuk-agrobiznes-ukrayini-zapidsumkami-2018-19-mr (in Ukrainian).

Cherevko, I. (2018). Poniattia nishevykh kultur ta yikhnie mistse u dyversyfikatsii silskohospodarskoho vyrobnytstva. Ahrarna ekonomika, 11(1-2), 5-14 (in Ukrainian).

Derzhavna sluzhba statystyky Ukrainy: ofits. veb-sait: ukrain. versiia. URL: http://www.ukrstat.gov.ua (in Ukrainian).

Khomiuk, N. L. (2019). Dyversyfikatsiia rozvytku silskykh terytorii $\mathrm{v}$ umovakh detsentralizatsii: monohrafiia. Lutsk: Vezha Druk (in Ukrainian).

Khomiuk, N. L. (2019). Napriamy dyversyfikatsii rozvytku silskykh terytorii $\mathrm{v}$ umovakh detsentralizatsii. Innovatsiina ekonomika, 5-6, 113-118. doi: 10.37332/2309-1533.2019.5-6.15 (in Ukrainian).

Khomiuk, N. L. (2020). Metodolohichnyi bazys doslidzhennia dyversyfikatsii rozvytku silskykh terytorii v umovakh detsentralizatsii. Prychornomorski ekonomichni studii, 50(2), 80-84 doi: 10.32843/bses.50-45 (in Ukrainian).

Khomiuk, N. L., \& Pavlikha, N. V. (2019). Kontseptualni pidkhody do rozvytku silskykh terytorii $\mathrm{v}$ umovakh detsentralizatsii. Rehionalna ekonomika, 3(93), 71-78. doi: 10.36818/1562-0905-2019-3-7 (in Ukrainian).

Khomiuk, N., Bochko, O., Pavlikha, N., Demchuk, A., Stashchuk, O., Shmatkovska, T., \& Naumenko, N. (2020). Economic modeling of sustainable rural development under the conditions of decentralization: a case study of Ukraine. Scientific Papers. Series: Management, Economic Engineering in Agriculture and Rural Development, 20(3), 317-332. URL: http://managementjournal.usamv.ro/index.php/scientif ic-papers/current.

Kundilovska, T. A., \& Zelenianska, N. M. (2018). Formuvannia rynku orhanichnoi produktsii $\mathrm{v}$ Ukraini. Visnyk sotsialnoekonomichnykh doslidzhen, 4(68), 137-147. doi: 10.33987/vsed.4(68).2018.137-147 (in Ukrainian),

Matvieiev, P. M. (2019). Zakordonnyi dosvid derzhavnoho rehuliuvannia u sferi pidvyshchennia produktyvnosti vykorystannia resursnoho potentsialu ahrarnoho sektoru. Ukrainskyi zhurnal prykladnoi ekonomiky, 4(3), 367-375. doi: 10.36887/2415-8453-2019-3-40 (in Ukrainian).

Mylovanov, Ye. V. (2018). Naikrashchi svitovi praktyky derzhavnoi pidtrymky orhanichnoho silskohospodarskoho vyrobnytstva ta perspektyvy dlia Ukrainy. Mechanism of Economic Regulation, 2, 14-33. doi: 10.21272/mer.2018.80.02 (in Ukrainian).

Pavlikha, N. V., \& Khomiuk, N. L. (2019). Metodychni pidkhody do analizu rozvytku silskykh terytorii. Rehionalna ekonomika, 1, 47-55. doi: 10.36818/15620905-2019-1-6 (in Ukrainian).

Pavlikha, N. V., \& Voichuk, M. V. (2018). Kontseptualni zasady upravlinnia stalym rozvytkom mista $\mathrm{v}$ umovakh yevropeiskoi intehratsii ta realizatsii reformy detsentralizatsii. Rehionalna ekonomika, 3, 29-36. URL: http://re.gov.ua/doi/re2018.03.029_u.php (in Ukrainian).

Pro osnovni pryntsypy ta vymohy do orhanichnoho vyrobnytstva, obihu ta markuvannia orhanichnoi produktsii: Zakon Ukrainy vid 10.07.2018 r. № 2496-VIII. URL: http://zakon.rada.gov.ua/laws/show/2496-19 (in Ukrainian).

Rosola, U. V. (2018). Suchasnyi stan ta rozvytok silskoho hospodarstva Zakarpatskoi oblasti na marketynhovykh zasadakh. Naukovyi visnyk Mukachivskoho derzhavnoho universytetu. Seriia "Ekonomika", 2(10), 115-119. doi: 10.31339/2313-8114-2018-2(10)-115119 (in Ukrainian).

Trofimtseva, O., \& Prokopchuk, N. (2018). Orhanichnyi rynok v Ukraini. URL: https://agropolit.com/spetsproekty/ 415-organichniy-rinok-v-ukrayini--analitika (in Ukrainian).

Tryhuba, A., Pavlikha, N., Rudynets, M., Tryhuba, I., Grabovets, V., Skalyga M., Tsymbaliuk, I., Khomiuk, N., \& Moroz, V. (2019). Studying the influence of production conditions on the content of operations in logistic systems of milk collection. Eastern-European Journal of Enterprise Technologies, 3/3(99), 50-63. doi: 10.15587/1729-4061.2019.171052. 